Reprod. Nutr. Dévelop., 1986, 26 (2 B), 731-743.

\title{
Newborn calf intestinal absorption of immunoglobulins extracted from colostrum
}

\author{
J.-F. GRONGNET, Elisabeth GRONGNET-PINCHON, D. LEVIEUX (*), \\ M. PIOT $\left({ }^{* *}\right)$, J. LAREYNIE
}

Chaire de Zootechnie, ENSA et Laboratoire du Jeune Ruminant, I.N.R.A., 65, rue de Saint Brieuc, 35042 Rennes Cedex, France.

(*) Laboratoire des Maladies nutritionnelles, I.N.R.A., Theix, 63122 Ceyrat, France.

(**) Laboratoire de Recherche de Technologie laitiere, I.N.R.A., 65, rue de Saint-Brieuc, 35042 Rennes Cedex, France.

\begin{abstract}
Summary. In the newborn calf, colostrum immunoglobulin absorption was compared with absorption of immunoglobulins extracted from colostrum. Reduced absorption of the latter resulted in plasma immunoglobulin levels unable to protect the animals against infections. Adding complete milk powder to the immunoglobulin solution slightly improved the level of absorption. Postprandial plasma alkaline phosphatases levels exhibited changes differing with the nature of the meals. This reinforces the idea that intestinal function was probably disturbed by immunoglobulin solutions. Moreover, reduced appetite for immunoglobulin solution was evident by the second meal, when most of the animals previously subjected to this diet suffered from a variety of problems (scour, asthenia), possibly caused by harmful effects of immunoglobulin solution on their digestive tract.
\end{abstract}

\section{Introduction.}

It is well known that copious ingestion of colostrum prevents sanitary problems in newborn ruminants and piglets (Dardillat, Trillat and Larvor, 1978). For colostrum to be effective, it must contain a sufficient amount of immunoglobulins (Stott and Fellah, 1983 ; Tshibangu et al., 1982) that are ingested soon after birth (Edwards et al., 1982 ; Stott et al., 1979) by lambs and calves which are able to absorb them. Very wide variations have been found between individual levels of plasma immunoglobulins after the ingestion of apparently similar quantities of pooled colostrum. These results led to studies on factors which might act on immunoglobulin absorption. Some authors considered the importance of environmental factors by studying :

- prepartum maternal feeding (Blecha et al., 1981 ; Grongnet, 1981 ; Halliday et al., 1978 ; Khalaf et al., 1979 ; Loh et al., 1971; Olson et al., 1981);

- ambient temperature (Blecha and Kelley, 1981; Cabello and Levieux, 1980 ; Kelley, Blecha and Regnier, 1982 ; Olson, Papasian and Ritter, 1980 ; Rafai et al., 1981 ; Stott et al., 1976 ; Stott, 1980) ;

- season of calving (Edwards, Broom and Collis, 1982 ; Frerking and Aeikens, 1978 ; Gay, McGuire and Parish, 1983 ; Gonzalez, Villouta and Ferrando, 1976 ; 
Selman, McEwan and Fisher, 1970; Smith, O'Neil and Simmons, 1967 ; Tshibangu et al., 1982) ;

- presence of the dam and methods of feeding colostrum (Fallon, 1978; Joly, 1981 ; Lomba et al., 1978 ; McCoy et al., 1970 ; Selman et al., 1971a, b ; Smith, O'Neil and Simmons, 1967 ; Stott et al., 1979 ; Stott, 1980);

- size of the litter (Halliday, 1978; Logan and Irwin, 1977);

- interval before first sucking (Edwards, Broom and Collis, 1982 ; Khalaf et al., 1979 ; Selman, McEwan and Fisher, 1970 ; Stott et al., 1979).

Other authors studied factors more closely related to the physiological state of newborn animals :

- prematurity and length of gestation (Cabello and Levieux, 1981a, b ; George et al., 1979) ;

- adrenal hormones (Boyd and Hogg, 1981; Cabello and Levieux, 1980 ; Daniels, Hardy and Malinowska, 1973 : Daniels et al., 1973 ; Gillette and Filkins, 1966 ; Halliday, 1959 ; Husband, Brandon and Lascelles, 1973 ; Johnston and Oxender, 1979 ; Morris and Morris, 1976 ; Patt and Eberhart, 1976 ; Rafai et al., 1981 ; Stott et al., 1976) ;

- thyroid hormones (Boyd and Hogg, 1981; Cabello and Levieux, 1981a, b ; Cabello et al., 1983 ; Pethes, Frenyo and Rudas, 1982) ;

- sex (Halliday and Williams, 1979 ; Norman, Hohenboken and Kelley, 1981);

- genotype (Boyd and Hogg, 1981 ; Joly 1981 ; Halliday et al., 1978 ; Halliday, 1979).

It should be noted that the results concerning most of these factors were often conflicting.

Such discrepancies also exist between results dealing with the influence of the physical-chemical features of the excipient mixed with the immunoglobulins. Their importance is far from negligible. Balfour and Comline (1962) noted a dramatic fall in absorption when immunoglobulins were administered in a saline solution, even if the solution was as well balanced ionically as colostrum. Luckily, a low molecular-weight protein, extracted from colostrum by these authors, restored absorption to a satisfactory level when added to their solution. Hardy (1969) established that adding potassium isobutyrate to a saline solution of immunoglobulins or polyvinylpyrrolidone increased intestinal absorption considerably ; Baumwart et al., (1977), who added the same substance to colostrum, did not confirm this.

Among other products studied, only poly-L-arginine had a beneficial effect (Smith, Witty and Brown, 1968). All the others such as duodenal fluid (James and Polan, 1978), histamine (Patt et al., 1972), cow saliva (Balbierz et al., 1976), L-methionine and L-leucine (Smith and Pierce, 1967), large quantities of glucose (Lecce, 1966) or lactose (Werhahn, Klobasa and Butler, 1981) were ineffective or detrimental to absorption. It should be noted that a clear comparative interpretation of the results is doubtful, given the widely different experimental conditions used.

Moreover, if any colostral component exerts a positive and direct action upon immunoglobulin absorption (Balfour and Comline, 1962), the very strong antitrypsic activity of colostrum seems to affect it, but in an indirect way, by preventing 
proteolysis. Once again, the results are very debatable (Baintner, 1973a, b ; Chamberlain, Perry and Jones, 1965 ; Jensen and Pedersen, 1982).

Among the factors affecting immunoglobulin absorption by the newborn calf, lamb and piglet intestine, those concerning the other constituents of the solution are of great importance today because cheap, orally dispensable, immunoglobulins would be produced industrially in the near future. Their efficiency will, of course, depend on how well they can be absorbed.

The aim of the present work was to compare the absorption of immunoglobulins extracted from colostrum with that of immunoglobulins remaining in the colostrum.

\section{Material and methods.}

Animals. - Three groups (A, B, C) of newborn male and female Holstein Friesian calves, born from the same dairy herd, were used. Group A (40 calves) was born during the winter of 1979-1980, group B (32 calves) during the winter of 19801981, and group C (23 calves) during the winter of 1981-1982. All were born spontaneously at term and without dystocia. Calving was often slightly accelerated by a mild traction exerted on the fore limbs of the calf after it appeared in the vulva of the dam. No pharmacodynamic agents were used to facilitate parturition.

Diets. - Twenty-eight hours after birth and twice a day thereafter, the calves were fed with a standard milk replacer. Previous to this, they were fed four times, at exactly $4,10,16$ and $22 \mathrm{~h}$ after birth. At those times, group A calves were fed on colostrum from the first milking of their dams. When several parturitions occurred at very short intervals, all the resulting colostra were mixed before feeding in order to homogenize the immunoglobulin levels as much as possible since there was no pooled colostrum already prepared; $25 \mathrm{~g} / \mathrm{kg}$ body weight (BW) were given each time to each calf.

The four meals of group $B$ animals consisted of an immunoglobulin solution (ISB); its basic composition is shown in table 1. This solution, using colostrum

TABLE 1

Elementary composition of immunoglobulin solutions. Comparison with colostrum.

\begin{tabular}{|c|c|c|c|c|c|}
\hline & $\begin{array}{l}\text { Dry matter } \\
(\%)\end{array}$ & $\begin{array}{l}\text { Immunoglobulin } \mathrm{G} \\
\qquad(\mathrm{g} / \mathrm{kg})\end{array}$ & $\begin{array}{c}\text { Ash } \\
(\mathrm{g} / \mathrm{kg})\end{array}$ & $\begin{array}{l}\text { Lactose } \\
(\mathrm{g} / \mathrm{kg})\end{array}$ & $\begin{array}{c}\text { Antitrypsic } \\
\text { activity } \\
(I T U / g)^{*}\end{array}$ \\
\hline Immunoglobulin solution ISB & 12,3 & 83,6 & 0,8 & 8 & 386 \\
\hline $\begin{array}{l}\text { Immunoglobulin solution ISC } \\
\text { Colostra }\end{array}$ & 11,7 & 86,1 & 0,7 & 6 & 479 \\
\hline $\begin{array}{l}\text { (Group } A \text {, all dams : } \\
\text { mean } \pm \text { SD) }\end{array}$ & $\mathrm{ND}^{* *}$ & $98,6 \pm 23,6$ & ND & ND & ND \\
\hline \multicolumn{6}{|l|}{ Reference pooled colostra } \\
\hline 1 (12 cows) & ND & ND & ND & ND & 461 \\
\hline $2(8$ cows $)$ & ND & ND & ND & ND & 458 \\
\hline
\end{tabular}

* ITU/g : inhibited trypsin unit ; ** ND : not determined. 
obtained at the first milking, frozen and thawed, was prepared by the following successive steps : - dilution $(x 2)$; - removal of fat by centrifugation; - dilution ( $x 3$ ) ; - casein coagulation at $\mathrm{pH} 4.6$ by addition of $\mathrm{HCl}, 6 \mathrm{~N}$; - removal of the insoluble by centrifugation; neutralization by $\mathrm{NaOH}$; - ultrafiltration, concentration and washing on Romicon, MP $100(\mathrm{R})$ membrane (nominal separation level : 100000 daltons) which retained the immunoglobulins in the retentate and removed $\alpha$-lactalbumin and $\beta$-lactoglobulin in the ultrafiltrate.

At the end of washing, the retentate was frozen in units of one liter. After each birth, it was thawed by warming in a mild water bath at not more than 40$50^{\circ} \mathrm{C}$. Considering the level of immunoglobulins $\mathrm{G}(\mathrm{lgG})$ in the retentate $(83.6 \mathrm{~g} / \mathrm{l})$ and the average level of $\mathrm{lgG}$ in the colostra used for group $A$ $(98.6 \pm 23.6 \mathrm{~g} / \mathrm{l})$, the delivery of the retentate at the rate of $29 \mathrm{~g} / \mathrm{kg} \mathrm{BW}$ allowed group $B$ calves to receive as much immunoglobulin as group A calves $(2.5 \mathrm{~g} / \mathrm{kg}$ BWI.

Examination showed that the retentate was pathogen-free and of satisfactory bacteriological quality.

Group $C$ was divided into three subgroups : 8 calves (subgroup $C 1$ ) received pooled colostrum obtained at the first milking, according to group A conditions ; 7 calves (subgroup C2) received an immunoglobulin solution (ISC, table 1) prepared as ISB ; 8 calves (subgroup C3) were treated as subgroup C2, except that $160 \mathrm{~g}$ of milk powder were added per $\mathrm{kg}$ of immunoglobulin solution. This restored the dry matter percentage to nearly that of usual first milking colostrum, obtained by biochemical components enclosed in the colostrum, for most of them.

The alimentary levels assigned to these three subgroups were calculated so that the quantity of $\mathrm{lgG}$ ingested per $\mathrm{kg}$ of body weight was the same as that administered to groups $A$ and $B$.

The four experimental meals were given to all the calves in a bucket fitted with a teat at the bottom. In case of mild inappetence, manual pressure was applied to the teat to facilitate ingestion. In case of acute inappetence, oesophageal intubation was practised.

Sampling and analysis. - Blood was taken by puncture of the jugular wein of every calf at the very moment of birth and at 4, 6 ( $7 \mathrm{~h}$ for group C), 10, 16, 22 and $28 \mathrm{~h}$ afterwards.

Similar sampling was carried out again 2, 3 and 4 days after birth and at the end of the first and second postnatal weeks. The level of IgG in blood plasma was determined by single radial immunodiffusion according to Mancini, Carbonata and Heremans (1965) and the level of alkaline phosphatase according to Bessey, Lowry and Brock (1946) using Boehringer-Mannheim (R) reagents. Cortisol was titrated in groups $A$ and $B$ according to Bosc and Fèvre. (1977) on blood samples collected at 0,6 and $22 \mathrm{~h}$ and 3 days after birth.

As for the immunoglobulin solutions (ISB and ISC, table 1), IgG levels were also measured by the method cited above in all the colostra used. Antitrypsic activity was measured according to Valdebouze et al. (1980) in the ISB and ISC solu- 
tions and in two pooled colostra not related to this experiment but used as a good reference because of the large number of individual colostra mixed.

All the bull calves in group $C$ were put into digestibility crates as soon as half an hour after birth, and their faeces were collected for $72 \mathrm{~h}$. The faeces of all calves were mixed, lyophilized, and the amount of $\operatorname{lgG}$ was determined in order to calculate the apparent digestibility (AD) of these proteins. $72 \mathrm{~h}$ was considered to be long enough to permit complete transit of the last, immunoglobulin-rich meal.

\section{Results.}

Vitality, appetite and general health of the calves. - The vitality of all calves was good during the four hours before the first meal. The various treatments did not apparently impair it, except for a female calf ( $N^{\circ} 209$ ) belonging to group $C 2$. This animal, exhibiting excellent vitality at birth, avidly ingested the first meal of immunoglobulin solution. She then refused to stand up, and died seventeen hours after birth. Postmortem examination revealed haemorrhagic enteritis of the jejunum.

A transient diarrhoea affected most of the animal of groups $B$ and $C 2$. The diarrhoea began at ten hours after birth and stopped approximately one day later. Its precocious and transient nature led us to exclude an infectious origin and, on the contrary, to suspect an alimentary one.

Colostrum meals were characterized by very few refusals (fig. 1), but this was not true of the immunoglobulin solutions. Although the first meal was ingested rather well (25\% refusals for group B, $0 \%$ for group $\mathrm{C} 2$ ), refusal rate reached a maximum at the second meal $(84$ and $88 \%$ for groups $\mathrm{B}$ and $\mathrm{C} 2$, respectively). The refusal rate pattern of group C3 was quite similar to that of group C2, although lower.

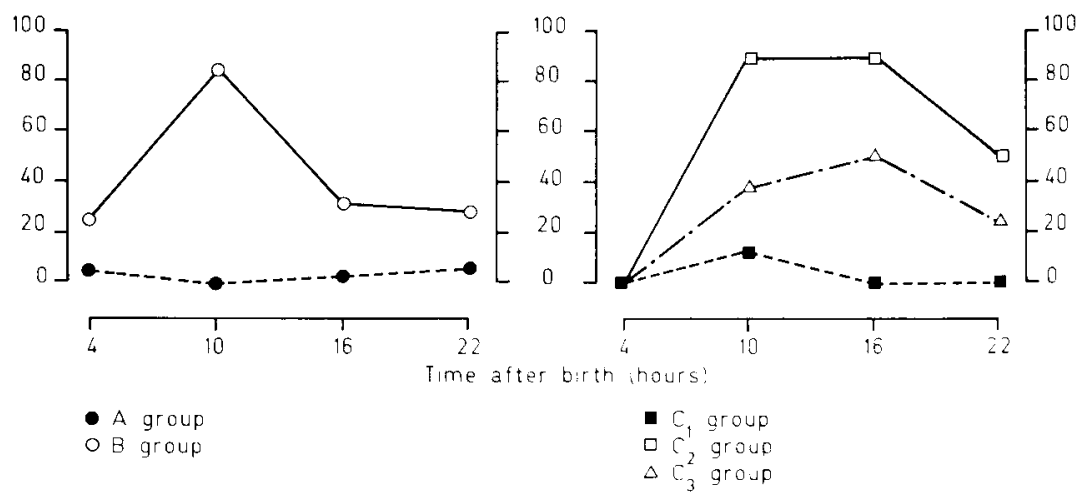

FIG. 1. - Percentage of refusals of the first meals after birth in dairy calves fed colostrum or immunoglobulin solutions.

The satisfactory levels of ingestion recorded at the first meal of immunoglobulin solution seem to demonstrate that the appetency of the immunoglobulin solutions was not the basic cause of the numerous refusals noted later. On the 
contrary, the first meal might have provoked digestive troubles, resulting in a general loss of appetite. On the other hand, this loss was corrected rather quickly since the refusal rate returned to a more reasonable level at the third and fourth meals.

The death of calf 209 and the excessively high refusal rates strengthen the notion that the immunoglobulin solutions were harmful to the digestive tract of the calves. The diarrhoeic episode reinforces this presumption, even if Selman, McEwan and Fisher (1970) noted a similar phenomenon in calves well fed with colostrum.

Immunoglobulins, alkaline phosphatase and cortisol in blood plasma; antitrypsic activity in colostrum and immunoglobulin solutions. - In all the groups, maximal plasma levels of immunoglobulins were found at 28 hours after birth (fig. 2), but the levels reached were very different : $32.8 \pm 1.9 \mathrm{~g} / 1$ in group $A$ and $25.4 \pm 3.5$ in group $C 1$. Groups which received the immunoglobulin solutions showed very low levels : $6.6 \pm 0.5$ in group $B$ and $8.6 \pm 1.3$ in group C2. Group C3, which received an immunoglobulin solution supplemented with milk powder, exhibited intermediate levels which were significantly higher than those of groups B and C2 between 16 and $96 \mathrm{~h}$ after birth. However, these levels were very different from those of groups $A$ and $C 1$.

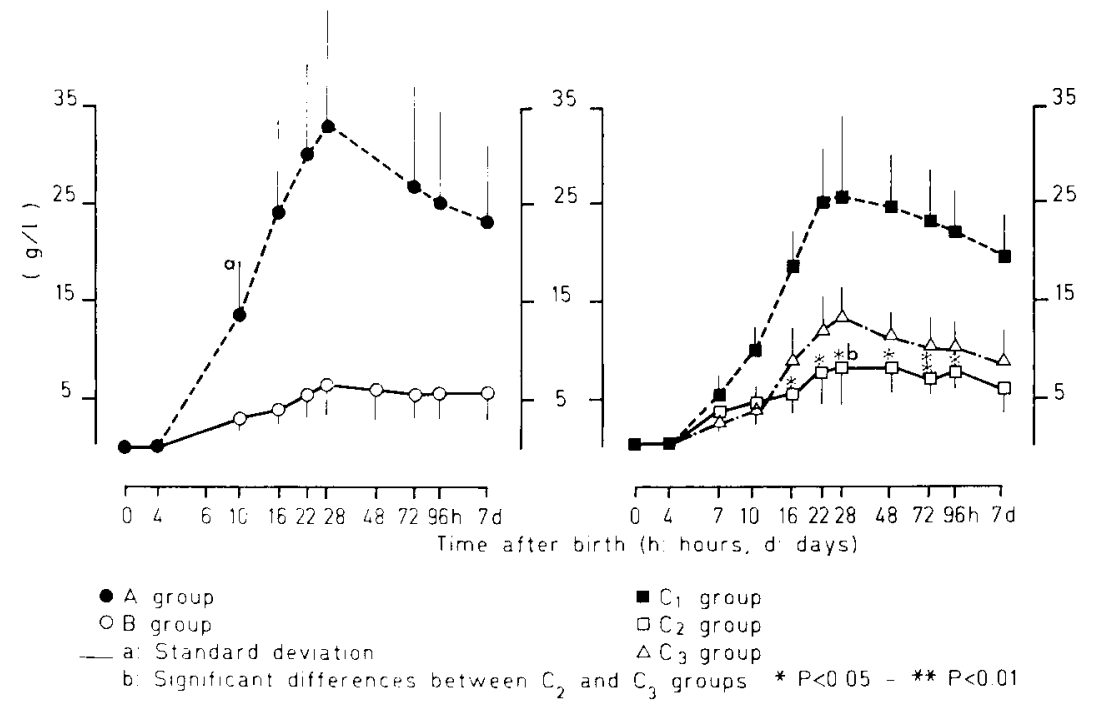

FiG. 2. - Changes in plasma lgG levels in neonatal dairy calves fed colostrum or immunoglobulin solutions.

Immunoglobulin apparent digestibility was $0.93 \pm 0.03$ for the colostrum diet, $0.91 \pm 0.02$ for the immunoglobulin solution alone and $0.85 \pm 0.06$ for the immunoglobulin solution mixed with milk powder.

Antitrypsic activity is shown in table 1 . The levels of this activity in relation to the immunoglobulin solutions were close to the values obtained with the two colostrum pools used as a reference. 
The first drink of colostrum started an abrupt rise in plasma alkaline phosphatase levels, followed by a decline some hours after (fig. 3). The patterns of the curves seemed to be specific to the diet : the rise was rapid and high in calves fed the immunoglobulin solutions, and the drop sudden and low. In calves fed colostrum, the curve was less sharp, resulting in levels significantly lower than those of groups B and C2 + C3 at the onset of the experiment (7 and $10 \mathrm{~h})$, and exceeding them afterwards $(16,22$ and $28 \mathrm{~h}$ ).

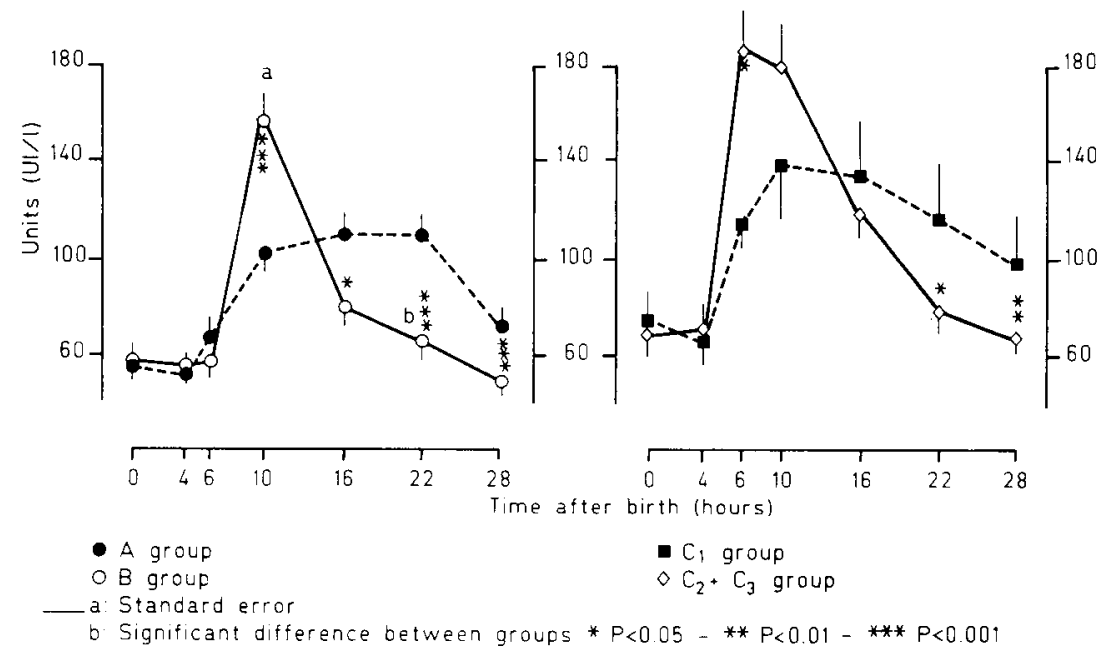

FIG. 3. - Changes in plasma alkaline phosphatase levels in neonatal dairy calves fed colostrum or immunoglobulin solutions.

In groups $A$ and $B$, cortisolemia was very high at birth (fig. 4) and decreased throughout the experiment. The group B levels, slightly more elevated at birth, became significantly higher than those of group $A$ later.

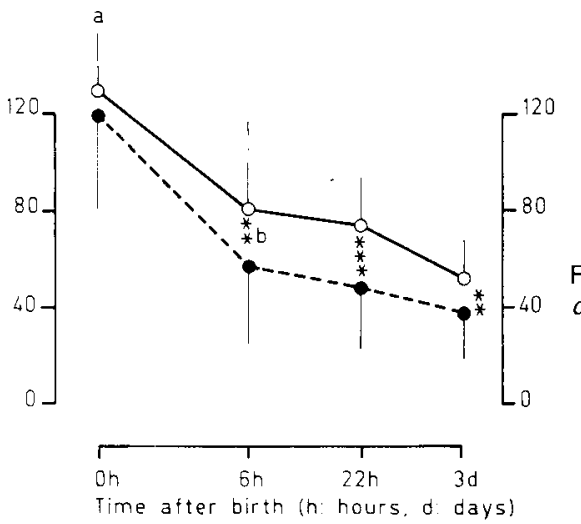

FIG. 4. - Changes in plasma cortisol levels in neonatal dairy calves fed colostrum or immunoglobulin solutions.

- A group

O g group

- a: Stanoard deviation

b. Significant differences between groups

** $\mathrm{P}<0.01$ - *** $P<0.001$ 


\section{Discussion.}

The groups fed colostrum exhibited a maximal plasma lgG level near to the highest values in the literature (Gay, McGuire and Parish, 1983 ; Stott et al., 1979). This was in agreement with the good conditions in which the meals were delivered and the ability of the calves to absorb immunoglobulins. Consequently, the very low levels recorded in the calves fed the immunoglobulin solutions must be regarded as resulting from the composition of this solution. This ineffectiveness is probably the outcome of extracting the low molecular-weight protein liable to intestinal immunoglobulin absorption or of removing the precursor of this molecule (Balfour and Comline, 1962). In our experiment, the improvement seen when milk powder was added to the solution would suggest that these products were also present in the milk but in lower quantities.

The immunoglobulin solutions used here also had a low osmotic pressure owing to their equally low concentrations of lactose and minerals (table 1). However, this feature must not be considered as the prime cause of malabsorption since Balfour and Comline (1962) observed the same phemonenon with a wellequilibrated solution. However, the fact that the osmotic pressure was too low would be at the origin of the harmful action of the immunoglobulin solutions on the calf digestive tract.

This unfortunate property seems to be established by the clinical observations cited above and confirmed by the changes in cortisolemia which increased rapidly in the animals fed the immunoglobulin solutions. Considering this last result some caution must be taken, since feeding such solutions, very poor of energy level could be considered as underfeeding. It has been noted in humans that fasting increases cortisolemia (Palmblad et al., 1977) and in the newborn calf itself that a delay in feeding colostrum postpones the decrease in cortisolemia, which is very high at birth (Lamotte and Eberhart, 1976; Nightengale and Stott, 1981).

The fate of the immunoglobulins which did not appear in the blood circulation of the calves fed the immunoglobulin solutions is unknown. They were not found in the faeces in a complete state because their apparent digestibility was high and did not differ from one diet to another. It must be remembered that the immunoglobulin levels were determined by an immunological method which would be ineffective if the molecule was fractionated.

Some proteolysis could have occurred (Kumano et al., 1976), but to a similar extent in the diets since the antitrypsic activity of the immunoglobulin solutions and the reference colostra were the same. Thus, the main reason for the wide differences between the plasma immunoglobulin levels could not be determined.

The rapid disappearance of immunoglobulins from the blood compartment due to a severe proteinuria was also unexpected. Such a phenomenon was already observed in the newborn calf by McDougall (1965), but it is unlikely that its intensity would depend so much on the type of diet.

There is no alternative but to admit with Matte et al. (1982) that a great part of the immunoglobulins seemed to be lost or, at least, was hardly perceptible by the means used here. However, after careful examination of the curves, a hypo- 
thesis can be proposed in relation to alkaline phosphatases (fig. 3). Healy (1975), in association later with Dinsdale (Healy and Dinsdale, 1979), was the first to report that a rise in plasma alkaline phosphatase levels always occurred at the time the immunoglobulins appeared in the blood circulation. This enzyme would be a part of the wall of subcellular vesicles containing immunoglobulins and released into the lymph circulation by enterocytes (Dinsdale and Healy, 1982). The enzyme is also present in colostrum (Linden and Maraval, 1979), but at a rate quite unable to account for the very high plasma concentrations after colostrum ingestion. This is contrary to gamma-glutamyl transferase, an enzyme appearing at the same moment and whose colostral origin has been determined by Braun et al. (1982).

Here, the origin of alkaline phosphatase is clearly endogenous and its abundance in plasma evidences a release of vesicles containing immunoglobulins. Therefore in groups $\mathrm{B}$ and $\mathrm{C} 2+\mathrm{C} 3$, after an extremely sharp rise, the levels suddenly dropped to significantly lower levels than those of the groups fed colostrum. This leads us to postulate a premature termination of transport, resulting in very low levels of plasma immunoglobulin. It should be noted, however, that cessation of transport does not necessarily mean cessation of absorption since, in the piglet, Baintner (1973a, b) measured the time-lapse between these two phenomena, an interval associated with the sequestration of immunoglobulins in the intestinal wall.

Conclusions. Colostrum is a very complex biochemical medium. It contains immunoglobulins required for the sanitary protection of the newborn animals. Besides these, colostrum also contains other factors, as yet poorly defined, which allow the immunoglobulins to be absorbed and transported. It is of interest to identify these factors because, if not, it will be impossible to carry out the project of feeding newborn ruminants with immunoglobulins industrially extracted from colostrum, blood serum and especially from lactoserum when maternal colostrum is lacking. It is clear that without these unknown factors, immunoglobulins are unable to pass into the plasma of newborn animals.

17 e Réunion du groupe Développement I.N.R.A., Montpellier, 22-24 mai 1985.

\section{Résumé. Absorption des immunoglobulines par le veau nouveau-né.}

L'exploitation industrielle des surplus de colostrum bovin étant envisageable à court terme, on a étudié, chez le veau nouveau-né, I'absorption intestinale des immunoglobulines extraites du colostrum par ultrafiltration. Quatre vingt quinze animaux issus du même troupeau laitier lors de trois campagnes de vêlage successives ont été répartis en lots suivant les règles expérimentales usuelles. Trois régimes ont été comparés : colostrum de première traite, solution saline d'immunoglobulines extraites du colostrum par ultrafiltration et solution saline d'immunoglobulines extraites du colostrum par ultrafiltration additionnée de poudre de lait entier. Les repas ont été administrés très exactement quatre, dix, seize et vingt deux heures après la naissance. Les quantités des différents régimes ont été ajustées de façon à ce que les quantités moyennes d'immunoglobulines reçues par les animaux fussent identiques. Des prélèvements sanguins réalisés suivant une cinétique précise, s'étendant de la naissance à vingt-huit heures de vie aérienne ont montré que les immunoglobulines con- 
tenues dans la solution saline étaient absorbées dans une très faible mesure. On a pu augmenter significativement cette absorption par l'adjonction de poudre de lait entier à la solution. Le dosage dans le plasma des phosphatases alcalines, issues pour la plupart de l'intestin, à ce stade de la vie, a montré que l'évolution de leur teneur était très dépendante du régime. Ceci pourrait attester de différences dans l'évolution du fonctionnement de l'intestin qui seraient provoquées par le régime mais pour lesquelles les auteurs ne sont pas en mesure, actuellement, de proposer une explication.

\section{References}

BAINTNER K., 1973a. The physiological role of colostral trypsin inhibitor : experiments with piglets and kittens. Acta vet. Acad. Sci. hung., 23, 247-260.

BAINTNER K., 1973b. Prolongation of the period of protein absorption : experiments with kittens and piglets. Acta vet. Acad., Sci. hung., 23, 279-289.

BALBIERZ H., NIKOLAJCZUK M., SAWICKI T., 1976. Observations on absorption of immunolactoglobulins in calves. Arch. Immunol. Ther. exp., 24, 55-62.

BALFOUR W. E., COMLINE R. S., 1962. Acceleration of the absorption of unchanged globulin in the newborn calf by factors in colostrum. J. Physiol., 160, 234-257.

BAUMWART A. L., BUSH L. J., MUNGLE M., CORLEY L. D., 1977. Effect of potassium isobutyrate on absorption of immunoglobulin from colostrum by calves. J. Dairy Sci., 60, 759-762.

BESSEY O. A., LOWRY O. H., BROCK M. J., 1946. A method for the rapid determination of alkaline phosphatase with five cubic millimeters of serum. J. biol. Chem., 164, 321-329.

BLECHA F., KELLEY K. W., 1981. Cold stress reduces the acquisition of colostral immunoglobulins in piglets. J. anim. Sci, 52, 594-600.

BLECHA F., BULL R. C., OLSON D. P., ROSS R. H., CURTIS S., 1981. Effects of prepartum protein restriction in the beef cow on immunoglobulin content in blood and colostral whey and subsequent immunoglobulin absorption by the neonatal calf. J. anim. Sci., 53, 1174-1180.

BOSC M., FEVRE J., 1977. Evolution de la cortisolémie au cours de la première semaine de vie, chez le veau et chez l'agneau. C.R. Acad. Sci. Paris, 284, 16-21.

BOYD J. W., HOGG R. A., 1981. Field investigations on colostrum composition and serum thyroxine, cortisol and immunoglobulins in naturally suckled dairy calves. J. comp. Pathol., 91, 193-203.

BRAun J. P., tainturier D., LAUgier C., BenARD P., thouvenot J. P., RiCo A. G., 1982. Early variations of blood plasma gamma-glutamyl transferase in newborn calves. A test of colostrum intake. J. Dairy Sci, 65, 2178-2181.

CABELLO G., LEVIEUX D., 1978. The effects of thyroxine and climatic factors on colostral gammaglobulin absorption in newborn calves. Ann. Rech. vét., 9, 309-318.

CABELLO G., LEVIEUX D., 1980. Comparative absorption of colostral immunoglobulin $\mathrm{G} 1$ and immunoglobulin $M$ in the newborn calf : Effects of $T 4$, cortisol and environmental factors. Ann. Rech. vét., 11, 1-8.

CABELLO G., LEVIEUX D., 1981a. Absorption and half-life of bovine, caprine and ovine IgG1 in the newborn lamb. Effect of experimental prematurity and endocrine factors. Ann. Rech. vét., 12, 421-429.

CABELLO G., LEVIEUX D., 1981b. Absorption of colostral lgG1 by the newborn lamb : influence of the length of gestation, birthweight and thyroid function. Res. vet. Sci, 31, 190-194.

CABELLO G., LEVIEUX D., LEFAIVRE J., 1980. The effect of intra-amniotic injections of thyroxine on the absorption of colostral lgG1 by the newborn kid. Br. vet. J., 136, 193-194.

CABELLO G., LEVIEUX D., GIRARDEAU J. P., LEFAIVRE J., 1983. Intestinal K99 ${ }^{+}$Escherichia coli adhesion and absorption of colostral lgG1 in the newborn lamb : effects of fetal infusion of thyroid hormones. Res. vet. Sci., 35, 242-244.

CHAMBERLAIN A. G., PERRY G. C., JONES R. E., 1965. Effect of trypsin inhibitor isolated from source colostrum on the absorption of $\alpha$-globulin by piglets. Nature, 207, 429.

DANIELS V. G., HARDY R. N., MALINOWSKA K. W., 1973. The effect of adrenalectomy or pharmacological inhibition of adrenocortical on macromolecule uptake by the newborn rat intestine. J. Physiol., 229, 697-707. 
DANIELS V. G., HARDY R. N., MALINOWSKA K. W., NATHANIELSZ P. W., 1973. The influence of exogenous steroids on macromolecule uptake by the small intestine of the newborn rat. $J$. Physiol., 229, 681-695.

DARDILLAT J., TRILLAT G., LARVOR P., 1978. Colostrum immunoglobulin concentration in cows : relationship with their calf mortality and with the colostrum quality of their female offspring. Ann. Rech. vét., 9, 375-384.

DINSDALE D., HEALY P. J., 1982. Enzymes involved in protein transmission by the intestine of the newborn lamb. Histochem. J., 14, 811-821.

EDWARDS S. A., BROOM D. M., COLLIS S. C., 1982. Factors affecting levels of passive immunity in dairy calves. Br. vet. J., 138, 233-240.

FALLON R. J., 1978. The effect of immunoglobulin levels on calf performance and methods of artificially feeding colostrum to the newborn calf. Ann. Rech. vét., 9, 347-352.

FOLEY J. A., OTTERBY D. E., 1978. Availability, storage, treatment, composition and feeding value of surplus colostrum : a review. J. Dairy Sci, 61, 1033-1060.

FRERKING H., AEIKENS T., 1978. About the importance of colostrum for the newborn calf. Ann. Rech. vét., 9, 361-365.

GAY C. C. G., MCGUIRE T. C., PARISH S. M., 1983. Seasonal variation in passive transfer of immunoglobulin $\mathrm{G} 1$ to newborn calves. J. Am. vet. med. Assoc., 183, 566-568.

GEORGE M., BALAKRISHNAN C. R., BHARGAVA R. K., RAJA C. A. R., 1979. Effect of gestation length on immunoglobulin absorption capacity of postnatal bovine calves. Ind. J. Dairy. Sci, 32, 475-476.

GILLETTE D. D., FILKINS M., 1966. Factors affecting antibody transfer in the newborn puppy. Am. J. Physiol., 210, 419-422.

GONZALEZ F., VILLOUTA G., FERRANDO G., 1976. Effect of management and season of calving on serum immunoglobulin levels in newborn dairy calves. Cien. Invest. Agrar., 3, 113-119.

GRONGNET E., 1981. Influence d'un régime materne/ prepartum riche en crucifères sur la vitalité, le métabolisme et les performances des veaux, au voisinage de la naissance. Th. $3^{\mathrm{e}} \mathrm{Cycle,}$ Rennes, $111 \mathrm{p}$.

HALLIDAY R., 1959. The effect of steroid hormones on the absorption of antibodies by the young rat. J. Endocrin., 18, 56-66.

HALLIDAY R., 1978. Immunoglobulin concentrations in Scottish Blackface lambs on a hill farm. Res. vet. Sci., 24, 264-266.

HALLIDAY R., 1979. La variabilité génétique du transfert d'immunoglobulines de la mère à ses produits. Ses effets sur la croissance et la viabilité. Bull. tech. Dép. Génét. anim., 29/30, 275283.

HALLIDAY R., RUSSEL A. J. F., WILLIAMS M. R., PEART J. N., 1978. Effects of energy intake during late pregnancy and of genotype on immunoglobulin transfer to calves in suckler herds. Res. vet. Sci., 24, 26-31.

HALLIDAY R., WILLIAMS M. R., 1979. The absorption of immunoglobulins from colostrum by bottle-fed lambs. Ann. Rech. vét., 10, 549-556.

HARDY R. N., 1969. The influence of specific chemical factors in the solvent on the absorption of macromolecular substances from the small intestine of the newborn calf. J. Physiol., 204, 607-632.

HEALY P. J., 1975. Isoenzymes of alkaline phosphatase in serum of newly born lambs. Res. vet. Sci., 19, 127-130.

HEALY P. J., DINSDALE D., 1979. Protein transmission in the intestine of newborn lamb: the involvement of acid and alkaline phosphatase activity. Histochem. J., 11, 289-298.

HUSBAND A. J., BRANDON M. R., LASCELLES A. K., 1973. The effect of corticosteroid on absorption and endogenous production of immunoglobulins in calves. Aust. J. exp. Biol. med. Sci., 51, 707-710.

JAMES R. E., POLAN C. E., 1978. Effect of orally administered duodenal fluid on serum proteins in neonatal calves. J. Dairy Sci, 61, 1444-1449.

JENSEN P. T., PEDERSEN K. B., 1979. Studies on immunoglobulins and trypsin inhibitor in colostrum and milk from sows and in serum of their piglets. Acta vet. scand., 26, 60-72.

JENSEN P. T., PEDERSEN K. B., 1982. The influence of sow colostrum trypsin inhibitor on the immunoglobulin absorption in newborn piglets. Acta vet. scand., 26, 161-168. 
JOHNSTON N. E., OXENDER W. D., 1979. Effect of altered serum glucocorticoid concentrations on the ability of the newborn calf to absorb colostral immunoglobulin. Am. J. vet. Res., 40, 3234 .

JOLY G., 1981. Contribution à l'étude de l'influence de la race, de la prématurité et de la présence maternelle sur l'acquisition de l'immunité passive par le veau. Mém. DEA, Rennes, $50 \mathrm{p}$

KELLEY K. W., BLECHA F., REGNIER J. A., 1982. Cold exposure and absorption of colostral immunoglobulins by neonatal pigs. $J$. anim. Sci, 55, 363-368.

KHALAF A. M., DOXEY D. L., BAXTER J. T., BLACK W. T. M., FITZSIMONS J., 1979. A note concerning the effects of ewe nutrition and colostrum deprivation on young lambs. Anim. Prod., 29, 411-413.

KUMANO Y., KANAMARU Y., NIKI R., ARIMA S., 1976. Occurrence of bovine IgG1 fragment in the faeces of the newborn calf. Jap. J. zootech., Sci., 47, 551-556.

LAMOTTE G. B., EBERHART R. J., 1976. Blood leukocytes, neutrophil phagocytosis and plasma corticosteroids in colostrum-fed and colostrum-deprived calves. Am. J. vet. Res., 37, 11891193.

LECCE J. G., 1966. Absorption of macromolecules by neonatal intestine. Biol. Neonat., 9, 50-61.

LINDEN G., MARAVAL B., 1979. Cow colostrum. Mineral composition and alkaline phosphatase activity. Ann. Biol. anim. Bioch. Biophys., 19, 337-342.

LOGAN E. F., IRWIN D., 1977. Serum immunoglobulin levels in neonatal lambs. Res. vet. Sci., 23. 389-390.

LOH K. R. W., SHRADER R. E., ZEMAN F. J., 1971. Effect of maternal protein deprivation on neonatal intestinal absorption in rats. J. Nutr., 101, 1773-1672.

LOMBA F., SPOONER R. L., MILLAR P., CHAUVAUX G., BIENFET V., 1978. Taux sanguins d'immunoglobulines, ingestion du colostrum et maladies des veaux nouveau-nés dans trois grandes unités. Ann. Méd. vét., 122, 101-107.

MANCINI G., CARBONARA A. O., HEREMANS J. H., 1965. Immunochemical quantitation of antigens by single radio-immunodiffusion. Immunochemistry, 2, 235-259.

MATTE J. J., GIRARD C. L., SEOANE J. R., BRISSON G. J., 1982. Absorption of colostral immunoglobulin $G$ in the newborn dairy calf. J. Dairy Sci, 65, 1765-1770.

McCOY G. C., RENEAU J. K., HUNTER A. G., WILLIAMS J. B., 1970. Effects of diet and time on blood serum protein in the newborn calf. J. Dairy Sci, 53, 358-362.

McDOUGALL E. I., 1965. Proteinuria of newborn suckling ruminants. Biochem. J., 94, 101.

MORRIS B., MORRIS R., 1976. The effects of corticosterone and cortisone on the uptake of poly. vinylpyrrolidone and the transmission of $\operatorname{lgG}$ by the small intestine in young rats. J. Physiol., 254, 389.

NIGHTENGALE G. T., STOTT G. H., 1981. Adrenal response of the newborn calf to acute inanition and colostral feeding. J. Dairy Sci, 64, 236-240.

NORMAN L., HOHENBOKEN W. D., KELLEY K. W., 1981. Genetic differences in concentration of immunoglobulins $\mathrm{G} 1$ and $\mathrm{M}$ in serum and colostrum of cows and in serum of neonatal calves. J. anim. Sci., 53, 1465-1472.

OLSON D. P. C., PAPASIAN C. J., RITTER R. C., 1980. The effect of cold stress on neonatal calves. 2. Absorption of colostral immunoglobulins. Can. J. comp. Med., 44, 19-23.

OLSON D. P., BULL R. C., WOODARD L. F., KELLEY K. W., 1981. Effects of maternal nutritional restriction and cold stress on young calves; absorption of colostral immunoglobulins. Am. $J$. vet. Res., 42, 876-880.

PALMBLAD J., LEVI L., BURGER A., MELANDER A., WESTGREN U., VON SCHENCK H., SKUDE G., 1977. Effects of total energy withdrawal (fasting) on the levels of growth hormone, thyrotropin, cortisol, adrenaline, noradrenaline, T4, T3 and T3 in healthy males. Acta med. scand., 201, 15-22.

PATT J. A., EBERHART R. J., 1976. Effects of metyropane and ACTH on intestinal absorption of immunoreactive bovine IgG in caesarean-derived pigs. Am. J. vet. Res., 37, 1409-1413.

PATT J. A., ZARKOWER A., EBERHART R. J., 1972. Effect of histamine on intestinal absorption of gamma globulins in newborn calves. J. Dairy Sci, 55, 645-646.

PETHES G., FRENYO V. L., RUDAS P., 1982. Changes of thyroid hormone levels in neonatal pigs and immunoglobulin absorption. Acta vet., 32, 187-192.

RAFAI P., FODOR E., FRENYO V. L., SCHULTZ E., 1981. Effect of adrenocortical function and microclimate on immunoglobulin absorption in calves. Acta vet. Acad. Sci. hung., 29, 53-64. 
SELMAN I. E., MCEWAN A. D., FISHER E. W., 1970. Serum immune globulin concentrations of calves left with their dams for the first two days of life. J. comp. Pathol., 80, 419-427.

SELMAN I. E., McEWAN A. D., FISHER E. W., 1971a. Studies on dairy calves allowed to suckle their dams at fixed times post-partum. Res. vet. Sci., 12, 1-6.

SELMAN I. E. MCEWAN A. D., FISHER E. W., 1971b. Absorption of immune lactoglobulin by newborn dairy calves : attemps to consistent immunoglobulin absorptions in newborn calves using standardised methods of colostrum feeding and management. Res. vet. Sci., 12, 205210.

SMITH H. W., O'NEIL J. A., SIMMONS E. J., 1967. The immune globulin content of the serum of calves in England. Vet. Rec., 80, 664-666.

SMITH M. W., PIERCE A. E., 1967. Effect of amino acids on the transport of bovine immunolactoglobulin across newborn pig intestine. Nature, 213, 1150-1151.

SMITH M. W., WITTY R., BROWN P., 1968. Effect of poly L-arginine on rate of bovine lgG transport by newborn pig intestine. Nature, 220, 387-388.

STOTT G. H., 1980. Immunoglobulin absorption in calf neonates with special consideration of stress. J. Dairy Sci., 63, 681-688.

STOTT G. H., FELLAH A., 1983. Colostral immunoglobulin absorption linearly related to concentration for calves. J. Dairy Sci., 66, 1319-1328.

STOTT G. H., MARX D. B., MENEFEE B. E., 1979. Colostral immunoglobulin transfer in calves. 4. Effect of suckling. J. Dairy Sci., 62, 1908-1913.

STOTT G. H., MARX D. B., MENEFEE B. E., NIGHTENGALE G. T., 1979. Colostral immunoglobulin transfer in calves. 3. Amount of absorption. J. Dairy Sci., 62, 1902-1907.

STOTT G. H., WIERSMA H. F., MENEFEE B. E., RADWANSKI F. R., 1976. Influence of environment on passive immunity in calves. J. Dairy Sci, 59, 1306-1311.

TSHIBANGU M. L., FUMIERE I., CHAUVAUX G., LOMBA F., BIENFET V., 1982. Importance de la quantité à globulines colostrales ingérées, de la teneur en anticorps du colostrum, du poids du veau et de la race dans l'acquisition d'une immunité maternelle suffisante. Rev. Agric., 35 , 3207-3213.

TSHIBANGU M. L., FUMIERE I., CHAUVAUX G., LOMBA F., BIENFET V., 1982. Influence de la saison et de l'heure de la naissance des veaux sur les variations de la distribution de colostrum et de l'immunité maternelle transmise dans trois unités bovines. Rev. Agric., 35, 3295 3312.

VALDEBOUZE P., BERGERON E., GABORIT T., DELORT-LAVAL J., 1980. Content and distribution of trypsin inhibitor hemagglutinins and in some legume seeds. Can. J. Plant Sci., 60, 695701.

VILLETTE Y., LEVIEUX D., 1981. Etude de l'influence de l'âge de la mère sur la transmission de l'immunité passive colostrale chez l'agneau. Ann. Rech. vet., 12, 227-231.

WERHAHN E., KLOBASA F., BUTLER J. E., 1981. Investigation of some factors which influence the absorption of $\mathrm{ggG}$ by the neonatal piglet. Vet. Immunol. Immunopathol., 2, 35-51. 